\title{
The shaping of the
}

\section{Lutheran teaching profession and Lutheran families of teachers in the 16th and 17th centuries}

\section{(illustrated by the example of the Trenčín, Liptov and Orava superintendency)}

\section{Libor Bernát}

Abstract: The article deals with changes in the status of teachers and the shaping of Lutheran families of teachers in the 16th and 17th centuries in the Trenčin, Liptov and Orava districts of the superintendency. It describes the formation of the families and their background.

Keywords: teacher, clergyman, family, school, study, teaching post, reformation, Catholic Reformation

In the 16th century Lutheran teachers faced fundamental changes as a consequence of the reformation, and one of its demands in particular - the end of the celebacy of clergymen, who represented a section of the intelligentsia, the elite, and constituted a class concerned with pastoral activities and education. The aim of this article is to investigate how the class of Lutheran teachers and their family relationships were established. The socio-economic status of this group will not be considered since it requires a study of its own.

Geographically, we will concentrate on the families in the regions of Trenčin, Liptov and Orava, which formed a separate superintendency ${ }^{1}$. The lesser autonomous districts were called seniorates. There were three seniorates in the region of Trenčin - Hornotrenčianske, Dolnotrenčianske and Hradňanské. They were quite independent and the superintendent (Bernát, 2007) was their only connection.

1 A superintendency is a district under the jurisdiction of a superintendent, the head of a dioceses of the Evangelical Church. 
The number of parish offices and schools depended on the political situation. There were some offices with no school at all (Slopná, Kolárovice, Kvačany and others) and some offices with not one but two schools (Liptovský Mikuláš and Okoličné, Dolný Kubín and Záskalie).

Noblemen and patrons had a key role to play - Count Juraj Thurzo (and his relatives), the Illésházy counts (Illyésházy, Iliesházy, Illésházy, Ilešházi), the Osztrosith barons (Osstrosic, Ostrosith, Ostrožič) and other landowners. Many of the members of these families had studied at foreign universities, in Wittenberg (Ján Ostrožič, Gašpar Suňog, Imrich Thurzo), Strasbourg (J. Ostrožič, Péter Révay), Tübingen (J. Ostrožič) and elsewhere. Naturally, they were influenced by the "paradigm" of the reformation and it manifested itself in their political, economic and educational activities.

These events resulted in a "turn" in the religion and helped to make religion a part of education. The teaching profession began to be regarded as the first stage in the clerical or pastoral profession.

The term "teacher" is used purposefully because at that time there was a difference between a rector (headmaster) and his assistants - conrectors, colleagues, teachers, etc. Positions tended to be referred to by several names. For instance, assistant teachers were referred to as collega, socius, locatus, Geselle, hypodidascalus, preceptor, magister, curator classis, synergus, Lehrer, auditor, and classicus.

Sometimes a teacher would hold several posts. For instance, Samuel Paulini, Sr. was both collega and teacher simultaneously in Ružomberok between 1584 and 1585. This would primarily happen in larger schools because in smaller schools they would only have one teacher. In the literature and resources, these positions tend to merge into one and any teacher is called a rector, which would not correspond with his status at school.

Sometimes a cantor (leader of a choir) would be a teacher and would continue his studies simultaneously, or he would interrupt his teaching activities to devote himself to his studies. For example, after completing his studies, Adam Corodini (Coroda, Corodinus, Korodini) was the cantor in Mošovce from 1606 to 1608 . Count J. Thurzo arranged for him to go to Wittenberg with a cover letter dated October 12, 1608. After completing his studies there he became the rector in Žilina in $1611 .^{2}$

There were teachers of young noblemen, too. These positions were not very lucrative and that is why these teachers tried to obtain posts in civic schools or to become deacons. However, these jobs could also help them to obtain new posts or enable them to travel with young noblemen.

2 Triplicis Ordinis Matriculae Ordinatorum, a Rndissimis Dominis Superintendentibus ... 1813, f. 132, The General Bishop's Office of the Evangelical Church of the Augsburg Confession in Slovakia, manuscript. No registration number. 
The teachers of parish offices would often become deacons - particularly in Považská Bystrica. At other times the post of deacon would become a starting post for a clergyman when leaving for another parish office.

But let us return to family issues. In terms of Hungarian law, the principle was that the social status of the child was based on the social status of the child's father. Thus the sons would often follow in their fathers' professions and become teachers or clergymen, and the daughters would marry other clergymen or teachers. There is an apt description of Bohemia and Moravia by Zikmund Winter: "Many a parish priest or a dean would tie a young clergyman to his family, offering his daughter's hand in marriage" (Winter, 1895).

In other words, a young teacher or clergyman would try to find a partner within his own community. Affections played only a marginal role.

A man was under the control of his family and had to conform to expectations and be devoted to the family. Basically the same is true for other reformed European countries. The pater familias played a key role in these families.

The life of a young teacher was focused on two equal aspects: career and family. Although the lives of husband and wife were closely linked, their social role was firmly predetermined. A wife was a housewife looking after her family, and a husband was primarily career-oriented. Their sons were expected to follow in their father's footsteps. Their daughters were expected to be good housewives and the parents would try to find a proper husband for them. From a legal point of view, the daughters were under the authority of their father until their marriage and under the authority of their husband after their marriage.

On numerous occasions the teachers became husbands without having to be clergymen, as opposed to some German regions where nearly one-third of clergymen (37.1\%) were married about four months after becoming clergy members (Wahl, 2000).

The information available does not satisfactorily answer the question of how old the women were on entering into marriage with teachers (clergymen). At marriage the men were aged from 24 to about 27. The legal age of marriage was 24 for men and 16 for women.

Due to difficulties in ascertaining the real age of a person, physical maturity was the deciding factor in those days (Malý \& Sivák, 1988). In second marriages we have found no case of the woman being older than the man.

There were even rare cases where a teacher (clergyman) had a daughter who was a single mother. Ondrej Kerner Očovský (Kernerius, Kernerus, Kerneris), the pastor in Kamenná Poruba, was one of them. His daughter was seduced, probably by the rector Ondrej Laurentii who was mistreated 
by the pastor and his son and the rector even communicated his complaint about this to the senior Eliáš Ladiver, Sr (Holuby, 1988).

Therefore, many families in this class were linked through marriage or baptism or tutorship. Baptism was important but there were differences in the ways it was carried out. The choice of godparents was important. A church order from Kremnica in 1558 required "that the godparents be devoutly urged to carry out their duties and pray to God for the faith of the infants..."(Križko, 1948).

In the case of the untimely death of the parents, the other teachers (clergymen) would become "the tutors" of the children of deceased relatives or friends. Ján Gažúr placed his son Matiáš (Michal) into the foster care of Matej Lochman and Tomáš Fabian from Mošovce. There were several similar cases.

The documents of the time cannot provide us with any information about adoption rates and related issues in the families examined.

Nepotism was strengthened through the consolidation of this class, the establishment of the seniorates and the creation of superintendencies. Families supported and favored their relatives. This was typical of Europe as a whole. In the Kingdom of Hungary it was typical not just of the Roman Catholic Church but of the Calvinist Church and the Unitas Fratrum as well.

The schools in Bánovce nad Bebravou and Bytča can be used as examples. In Bánovce there were six Lányis and in Bytča there were five, not including Eliáš Lányi, the first superintendent of Trenčin, Liptov and Orava.

Moreover, it was not uncommon for a father and later his son to be teachers at the same school. For example, this was true of Juraj and Zachariás Clementis and Eliáš Ladiver, Sr. and Eliáš Ladiver, Jr. in Žilina, and Ján and Teodor Sopúšek in Trenčín, etc.

Personal references were important and future career prospects could be improved if a person was depicted in a flattering light within an influential family. For instance, the rector Leonard Mokošini (Mokoschini, Mokoschinus) in Partizánska Lupča recommended his student Jakub Cebani (Czebanius, Czebonius Briznensis Pannonius) to his brother Juraj who was the pastor in Boca. Cebani would go on to become Juraj's deacon (Prónay \& Stromp, 1905).

Close relationships were formed amongst those studying as well. Students would often attend several schools. For example, Juraj Clementis studied alongside Ján Krman, Sr. and Krman's daughter Rebeka would later go on to become Clementis' wife.

The students would often follow their favorite teacher to his new teach- 
ing position. Almost all of the clergymen in the region under examination had taught before becoming clergymen, so it was not uncommon for them to meet their former students who had already become teachers or clergymen. For example, Matej Hranica (Hranicza, Hranicenus, Hranický), the rector in Bojnice, would go on to become the pastor in Žabokreky nad Nitrou. He offered a teaching post to his former student Vavrinec Sartoris in 1609 (Triplicis Ordinis ..., f. 6).

Nowadays we would call it lobbying.

Many of the village teachers, unable to attend the leading schools in the Kingdom of Hungary or one of the foreign schools, taught at village schools for a long time. Their hopes of a better teaching post or of becoming clergymen had never been fulfilled.

At some parish offices (Drietoma, Rajecká Lesná, Udiča, Višňové, Žaškov, etc.) none of the teachers we know of became ordained priests. Their social power was very limited and their social responsibility negligible. On the other hand, in other villages and small towns like Bobot and Uhrovec all of the teachers were ordained as priests.

Some of the teachers would migrate to obtain a better teaching post. A wealthy landowner would often move teachers and clergymen from one region to another. This kind of migration was not restricted by either the superintendency or the seniorates. For instance, the Balaš (Balassa) family owned land in the regions of Trenčin and Novohrad, so Eliáš Institoris Mošovský was the rector in Považská Bystrica from 1620, then he was the pastor in Luboreč from 1622, and in Udiča from 1628.

Many of the rectors (deacons) married into the families of pastors. This was quite understandable because the pastor was obliged to "set the table" for them every Sunday and on feast days. The rectors had close relationships with the pastor's family. The pastors used to make use of the situation to marry off their daughters. For instance, Samuel Paulini, Jr., the pastor in Rajec, wanted his daughter Justina to marry the rector Ondrej Fabricius (Fabrina, called Miško). Their disagreement was so intense that the rector had to leave Rajec and later became the pastor in Liptov.

There are no genealogies of these families which would allow us to determine how many pastors' and teachers' daughters married teachers or clergymen. Based on the available data we estimate that every fourth or fifth adult daughter was one of them.

The married couple was supposed to live moderately and in accordance with good manners. They were supposed to serve as an example of a peaceful, devout, diligent and family life.

These couples represented a united community and collectively they were 
supposed to show how to live an exemplary life. On the other hand, any one of these couples could be punished for their transgressions.

These families were prevented from advancing further by marital obstacles firmly specified in family law. This applied mainly to blood relatives. There was even a legal kinship, i.e. a kind of adoption or brother-in-law, and a spiritual kinship between godparents and godchildren. The obstacles were not absolute and the engaged couple could request to be exempted from them (Malý \& Sivák, 1988).

A marriage was terminated by the death of the husband or wife (or by the pronouncement of his or her death). We found no cases of separation (divorce).

Even though teachers were obliged to be in mourning for their deceased wives, they would often marry another woman quite quickly after the funeral. The wife of a deceased teacher would often marry another man soon after the funeral. It was a matter of survival. The death of a husband meant the loss of a breadwinner.

On the other hand, a teacher needed someone to keep house and to show that a Christian family could become a reality. Thus the well-known teacher (pastor) Eliáš Ladiver, Jr. was married four times. Older men especially needed someone to take care of them. Such is the case of John Amos Comenius whose third wife was a very young Jana Gajusová from Týn nad Vltavou. From the legal point of view, old age was reached at 60. We have not discovered any teacher marrying after reaching the age of 60. Even after reaching 45 , a daughter or some other female relative kept house for a teacher whose wife had passed away.

Nonetheless, women were not personally free and legally independent. The words of Apostle Paul in the Bible make this point clear: "Let your women keep silence in the churches: for it is not permitted unto them to speak; but they are commanded to be under obedience, as also saith the law". (1Cor.14:34, compare with 11:5-12).

The lives of the wives of teachers are quite hard to recount. There are no sources, and what we have was written by men. The wives were supposed to be a sort of "mistress of the house", "companion" to the teachers. Their lives were completely subordinate to those of the men.

There is basically no information available about their literacy or education. Some of them could write, that much we know, like Judita Masníková, the wife of the rector Matej Domkovič in Dolný Kubin and later in Dubnica nad Váhom, but this seems to have been a rarity. Legally, the male gender was considered to be sexus dignior - a superior gender. 


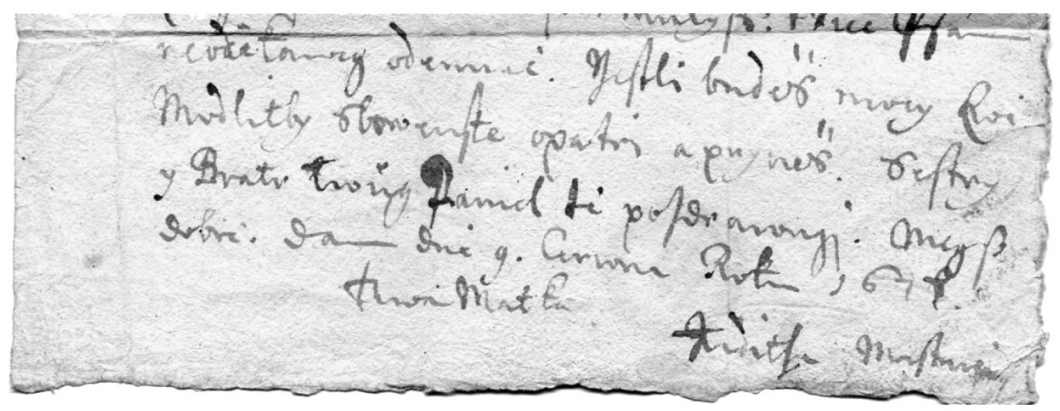

Figure 1 The closing part of a letter by J. Masníková with her signature sent to her son J. Domkovič in Levoča

SNK ALU Martin 155 G 46

Having a large number of children placed considerable demands on the mother. Thanks to the high birth rate, many of the families could grow and strengthen their influence (the number of rectors and pastors in the Trenčín, Liptov and Orava superintendency are stated in parentheses).

Table 1 Alphabetical list of the families of teachers working in the regions of the superintendency under investigation ${ }^{3}$

\begin{tabular}{|c|c|c|c|}
\hline Family & Number & Related families & Number \\
\hline \multirow[t]{5}{*}{ Augustíni } & 2 & Bombicenus & 1 \\
\hline & & Haler & 1 \\
\hline & & Regis & $\square$ \\
\hline & & Rutkai & 1 \\
\hline & & Šmidelius & 2 \\
\hline \multirow[t]{3}{*}{ Benedikti } & 2 & Jakobei & 1 \\
\hline & & Krman & $\square$ \\
\hline & & Smrtník & 1 \\
\hline Clementis & 3 & & \\
\hline \multirow[t]{4}{*}{ Clementis (2) } & 3 & Hieronymi & 1 \\
\hline & & Krman & $\square$ \\
\hline & & Regis & $\square$ \\
\hline & & Rozinský & 1 \\
\hline Čutka & 3 & & \\
\hline \multirow[t]{3}{*}{ Doršic } & 4 & Mazurka & 1 \\
\hline & & Mokošini & $\square$ \\
\hline & & Žár & 1 \\
\hline Fabianides & 3 & & \\
\hline
\end{tabular}

3 Only family members working in this particular region are listed. 


\begin{tabular}{|c|c|c|c|}
\hline Family & Number & Related families & Number \\
\hline Fabricius & 4 & & \\
\hline Fabricius (2) & 3 & Jakobaei & $\square$ \\
\hline \multirow[t]{3}{*}{ Hadík } & 6 & Chalupka & $\square$ \\
\hline & & Krišpín & 1 \\
\hline & & Pilárik & 2 \\
\hline \multirow[t]{4}{*}{ Hrabec } & 3 & Clementis & $\square$ \\
\hline & & Levius? & $\square$ \\
\hline & & Regis & $\square$ \\
\hline & & Tranovský & $\square$ \\
\hline Chalupka & 6 & Hadík & $\square$ \\
\hline Institoris & 3 & Blasius & 1 \\
\hline \multirow[t]{2}{*}{ Jakobei } & 3 & Fabricius & $\square$ \\
\hline & & Tranovský & 1 \\
\hline Jeleň & 2 & Oekonom & 1 \\
\hline \multirow[t]{6}{*}{ Kalinka } & 3 & Augustini & $\square$ \\
\hline & & Lochman & 2 \\
\hline & & Marklovský & 1 \\
\hline & & Mokošini & $\square$ \\
\hline & & Tarnóci & 1 \\
\hline & & Vranka & $\square$ \\
\hline \multirow[t]{5}{*}{ Krman } & 3 & Benedikti & $\square$ \\
\hline & & Clementis (2) & $\square$ \\
\hline & & Fabri & $\square$ \\
\hline & & Masník & $\square$ \\
\hline & & Paulini & 2 \\
\hline \multirow[t]{3}{*}{ Láni } & 6 & Rebierko & 1 \\
\hline & & Sinapius & $\square$ \\
\hline & & Splénius & 2 \\
\hline Láni (Caban) & 3 & & \\
\hline Lišovini & 4 & Sarorius (3) & 2 \\
\hline \multirow[t]{5}{*}{ Masník } & 2 & Krman & $\square$ \\
\hline & & Domkovič & 1 \\
\hline & & Schrötter & $\square$ \\
\hline & & Fabricius & 1 \\
\hline & & Sartorius (1) & $\square$ \\
\hline Mikuláš & 2 & Peták (1) & 2 \\
\hline \multirow[t]{5}{*}{ Mokošini } & 2 & Doršic & $\square$ \\
\hline & & Thuroci & 2 \\
\hline & & Chmel & 1 \\
\hline & & Kalinka & $\square$ \\
\hline & & Lochman & $\square$ \\
\hline
\end{tabular}


The shaping of the Lutheran teaching profession and Lutheran families of teachers...

\begin{tabular}{|c|c|c|c|}
\hline Family & Number & Related families & Number \\
\hline & & Melik & 1 \\
\hline Monkovicenus & 3 & Tranovský & $\square$ \\
\hline Paršic & 2 & Ladiver & 2 \\
\hline \multirow[t]{2}{*}{ Petrovič } & 5 & Frivaldský & 1 \\
\hline & & Clementis & $\square$ \\
\hline \multirow[t]{3}{*}{ Rajtini } & 2 & Cehener & 2 \\
\hline & & Duchoñ & $\square$ \\
\hline & & Nicolaides & $\square$ \\
\hline \multirow[t]{2}{*}{ Sartoris(1) } & 4 & Major & 1 \\
\hline & & Masník & $\square$ \\
\hline \multirow[t]{3}{*}{ Sartoris(2) } & 2 & Carbonarius & 1 \\
\hline & & Huldenreich & 1 \\
\hline & & Majtan & 1 \\
\hline \multirow[t]{2}{*}{ Schrötter } & 3 & Dianiš & 1 \\
\hline & & Duchoň & $\square$ \\
\hline \multirow[t]{5}{*}{ Sinapius } & 4 & Hrehuš & 1 \\
\hline & & Kvetoň & 1 \\
\hline & & Ladiver & $\square$ \\
\hline & & Láni & $\square$ \\
\hline & & Matthaei & 1 \\
\hline Sopúšek & 4 & Žitkius & $\square$ \\
\hline Stránovský & 2 & Bapčáni & 1 \\
\hline Škrovina & 2 & Zvarecký & 1 \\
\hline \multirow[t]{4}{*}{ Telkonius } & 2 & Dokmovič & $\square$ \\
\hline & & Jastrebiny & 2 \\
\hline & & Marček & 1 \\
\hline & & Urbanovič & $\square$ \\
\hline \multirow[t]{3}{*}{ Túrsky } & 1 & Aparius & 1 \\
\hline & & Dropko & 1 \\
\hline & & Dubravius & 1 \\
\hline Tvrdý & 2 & Nosko & 1 \\
\hline \multirow[t]{3}{*}{ Urbanovič } & 3 & Domkovič ? & $\square$ \\
\hline & & Marček? & $\square$ \\
\hline & & Telkonius & $\square$ \\
\hline \multirow[t]{4}{*}{ Vranka } & 1 & Müller & 2 \\
\hline & & Kalinka & $\square$ \\
\hline & & Molitor & 2 \\
\hline & & Majtán & $\square$ \\
\hline \multirow[t]{2}{*}{ Žitkius } & 2 & Sopúšek & $\square$ \\
\hline & & Frano & 1 \\
\hline Total number: & 119 & & 63 \\
\hline
\end{tabular}


As the table indicates, the largest numbers of teachers were from the following families: Hadik (6), Chalupka (6), Lányi (6, excluding the Caban branch), Petrovič (5), Doršič (4), Fabricius (4), Lišovíni (4), Sartorius (4), Sinapius (4) and Sopúšek (4). The total number of teachers was 119. An additional 63 teachers can be added from the families into which a teacher married. Thus we obtain a total number of 182 teachers in the superintendency. Teachers from the families who did not work in the superintendency are not included.

This means that 316 teachers and clergymen came from the families listed.

Apart from these families, there were fathers and sons, brothers, uncles, nephews and cousins working in the superintendency. In total they numbered 24 couples.

We decided to include only one of the teacher's known workplaces in the following alphabetical list: cantor Ján Apostolus, Sr. in Liptovský Mikuláš and his brother-in-law Michal Chmel, Jr. who was a conrector in Žilina, teachers Juraj and Mojžiš Bánovský in Žilina, Peter Baroš, a rector in Trenčín, and Mikuláš, a rector in Ilava, teachers Ondrej Beniamides Sr. and Jr. in Lednica, cousins Eliáš Berger and Alexander Socovský who were rectors in Trenčín, teachers Michal Caban, Sr. in Partizánska Lupča and Michal Caban, Jr. in Varín, collega Blažej Fábri in Žilina and his son Juraj Fabricius who was a teacher in Bánovce nad Bebravou, rectors Eliáš and Pavol Faško in Okoličné who were brothers, rectors Matej and Gašpar Gažúr in Ilava, rectors Matej and Ján Haberman (Habrman, Habrmann) who were father and son in Kysucké Nové Mesto, rectors Ondrej Hieronimi, Sr. and his son Izák in Dolný Kubín, Juraj Kazar, Jr. who was a rector in Dolný Kubín, and his son Ján who was a rector in Hybe, rector Štefan Krušpier, Sr. in Žilina and his son Štefan who was a rector in Kysucké Nové Mesto, rector Ján Lukáč in Lokca and his son Ondrej who was a cantor in Liptovská Teplá, rector Ján Lycius in Ružomberok and his son Juraj who was a rector in Trenčín, collega Mikuláš Martinko (Martinkius, Martiny Martiny) in Bytča and his brother Samuel who was the rector in Súlov, rectors Mikuláš Nigrini Oškeredský and his son Samuel in Žilina, rector Vavrinec Osvald (Osvaldi, Oswaldi) in Rajec and his son Štefan who was a teacher in Bánovce nad Bebravou, rectors Martin Rotarides and his son Izaiáš in Veličná, cantor Matej Rudinský in Ilava and his son who was a cantor in Liptovský Mikuláš, rector Pavol Zachenský (Zachemský, Zachemszky) in Okoličné and his brother or son who was a rector in Partizánska Lupča.

Due to the lack of available data, the average number of children in teachers' families remains unknown to us. Some families were childless but some had 24 or 25 children. 
Table 2 The numbers of schools, teaching posts and teachers in the Trenčin, Liptov and Orava superintendency

\begin{tabular}{|l|c|c|c|c|}
\hline \multicolumn{1}{|c|}{ Seniorate } & Schools & $\begin{array}{c}\text { Teaching } \\
\text { posts }\end{array}$ & Teachers $^{4}$ & $\begin{array}{c}\text { Ordained } \\
\text { rectors }\end{array}$ \\
\hline Hradňanský & 10 & 88 & 86 & 35 \\
\hline Dolnotrenčiansky & 21 & 205 & 143 & 56 \\
\hline Hornotrenčiansky & 16 & 275 & 201 & 67 \\
\hline Oravský & 16 & 126 & 99 & 39 \\
\hline Liptovský & 31 & 372 & 317 & 94 \\
\hline Total & 94 & 1013 & 823 & 291 \\
\hline
\end{tabular}

Source: Bernát, 2001

There were schools with many teachers but some village schools had just a few teachers. Not every parish office had a school. In some of the smaller parish offices (Bielice, Dobrá, Kamenná Poruba, Boca, etc.) there was no school at all. It is interesting to note that in the Orava seniorate there was not a parish office that did not have a school. Some of the larger parish offices even had two schools.

The total number of clergymen and teachers was 1305 and 316 of them $(24.21 \%)$ were from the families under investigation. If we add another 37 pairs consisting of fathers and sons and brothers, we arrive at a figure of $29.88 \%$. We estimate that we have no data on about $10 \%$ of the families. That means that one-third of the pastors and rectors came from these families.

The families of clergymen and teachers were able to give the children a solid foundation on which to build. For example, in the large Lišovini family there were four physicians - Ján Lišovíni (* 1680), Ján Lišovíni (1713-1757), Ondrej Lišovíni (1672-1714?) and Samuel Dávid (the 1700s).

The increasing number of educated persons even made it possible for some of the member of these families to find work abroad, where there were also better conditions, earnings, circumstances and more religious tolerance. Religious tolerance was only an issue for a small number of educated persons, mainly those leaning towards Calvinism, the Unitas Fratrum or Utraquism.

These were Slovak figures who spoke Slovak as their mother tongue, which helped to create more favorable conditions for the national intelligentsia to emerge (Kuzmik, 1976).

1 Some teachers held more than one teaching post.

2 Only ordained rectors in the seniorates are included. 
The families established roles as "mavens" (or experts) (Gladwell, 2006). The family members would become experts or "masters" in a particular field of study. Therefore, it is understandable that several members of these families would hold several important posts in seniorates.

The families even included several foreigners from Bohemia and Moravia (Adami, Perlička, Petrozelinus, Šumberg), Germany (Haler, Krman, Paulini, Sinapius), Silesia (Tranovský) and Poland. Alexander Karol Curtius (Kurtius) who was the rector in Partizánska Lupča, was from Lithuania.

By the end of the 17th century, the Catholic Reformation (Counter-Reformation) had already started to take effect, with Catholic clergymen and teachers becoming more prominent. The number of evangelical intelligentsia decreased and jobs were harder to find.

The Catholic Reformation, wars and suffering left scars on the teachers' families. The families of evangelical teachers were in decline and conversion to the Catholic faith started to become more prevalent. Village teachers were more likely to change religion and adopt the Catholic faith because of their social status.

Nevertheless, the role that the families of evangelical teachers played in the national revival was important. But that is a different topic to be dealt with.

\section{References}

Bernát, L. (2001). Dejiny školstva v dolnotrenčianskom senioráte v 16. a 17. storočí. Pedagogická revue, 53 (4), 341-362.

Bernát, L. (2001). Dejiny školstva v hornotrenčianskom senioráte v 16. a 17. storočí. Pedagogická revue, 53 (1), 62-76.

Bernát, L. (2004). Dejiny školstva v oravskom senioráte v 16. a 17. storočí. Pedagogická revue, 56 (5), 492-512.

Bernát, L. (2007). Pastori a pedagógovia v superintendencii Trenčianskej, Liptovskej a Oravskej v 16. a 17. storočí. Slovenská štatistika a demografia, 17 (3), 62-92.

Bernát, L. (2003). Školstvo v hradňanskom (záhorskom) senioráte v 16. - 17. storočí. Pedagogická revue, 55 (4), 378-391.

Gladwell, M. (2006). Bod zlomu. O malých prúčinách s velkými následky. Praha: Dokořán.

Križko, P. (1948). Dejiny banskomestského seniorátu. Liptovský Mikuláš: Tranoscius. Kuzmik, J. (1976). Slovnik autorov slovenských a so slovenskými vztahmi za humanizmu. I. A-M. Martin: MS.

Malý, K. \& Sivák, F. (1988). Dẽjiny státu a práva v Československu do r. 1918. I. díl. Praha: Panorama.

Prónay, D. \& Stromp, L. (1905). Monumenta historica evangelicorum in Hungaria. Budapestini: V. Hornyánszky.

Wahl, J. (2000). Lebensplanung und Alltagserfahrung. Wüttembergische Pfarrfamilien im 17. Jahrhundert. Mainz: Verlag P. von Zabern. 
Winter, Z. (1895). Život církevní v Čechách. Kulturně-historický obraz z XV. a XVI. století. Praha: Nákladem české akademie císaře Františka Josefa pro vědy, slovesnost a umění.

\section{Historical sources:}

\section{Archiv biskupského úradu Nitra}

Kanonická vizitácia 1688, kniha č. 2, f. 16

\section{Cirkevný zbor ECAV na Slovensku, Lyceálna knižnica Kežmarok}

Annales Statum Ecclesiarum Lyptoviensis Comitatus ... Joach. Kalinkii ... A 1647. 1653. 1666. MS 1936 Odpis nechal urobit Imrich Pongrácz v XVIII. stor. ružomberským farárom Pavlom Kešmarským

Farský úrad evanjelickej cirkvi a. v. v Istebnom,

Protocollum Scholae Istebnensis ab Anno 1789 ... bez ev. čísla.

\section{Farský archiv SECAV v Súl'ove}

KRIŽAN, J.: Dejiny artikulárnej niekdy cirkvi ev. a. v. súlouskej. Dl’a rukopisu neboh. Jána Križana farára sulovského zostavil Miloslav Križan ev. a. v. slova Božieho kazatel. Súlov, rkp. nedat.

\section{Knihovna Národniho muzeum v Prahe}

Akta Jednoty bratrské XIV., f. 470a-470b

\section{SR SNA Bratislava}

Rodový archív Zayovcov z Bučian, Písomnosti podla II. zväzku elenchov L. Balogha z r. 1862, 22. Písomnosti týkajúce sa protestantov v Uhorsku 1615-1822

\section{SR ŠA v Bytči}

Oravská župa, šlachtické písomnosti, spisy, fasc. 1, 1684, no. 1, Ambrózy, fasc. 2, 1715, no. 2, Matheides, 1716, no. 3/a Mathesius

Oravský komposesorát. Thurzovská korešpondencia 1511-1676. II. Listy písané J. Thurzovi 164 II-F/2

Fond Zsolnay zo Sedličnej (1261) 1533 - 1896, škatula č. 10, Rôzne. Protocollum rerum miscellanearum, 1. zošit

Zbierka cirkevných matrík:

193 I Matricula ecclesia Dubnicensis 1667-1793

383 II. Farnost' Košeca úmrtná matrika 29. I. 1773-26. XII. 1841

386 V matrika sobášna 11. I. 1750-10. XI. 1841

Matrika cirkve ev. aug. v. púchovskej od R. P. 1784. I. zv. i. č. 875, 981 I Matrica baptisatorum 5. IV. 1699-19. XII. 1726 Sedliacka Dubová

\section{SR ŠA v Bytči, pobočka Dolný Kubin:}

Geburová pozostalost', Oravské evanjelické fary a ich kñazi. Od počiatku reformácie do r. 1781. Príspevok $k$ cirkevným dejinám Oravy. nedat. strojopis a rkp. b. d.

Cirkeuný zbor ECAV v Dolnom Kubine, 1709. 1611-1709 Poznámky o farách na Orave. Zoznamy ev. kñazov a učitelov, Catalogus Ecclesiarum Euangelicar. Aruensium, nestr. Kronika škôl inv. č. 134/928 


\section{SR ŠA v Bytči, pobočka Liptovský Mikuláš,}

Annales ciuitatis Lypcae Allemanorum ... 1579, mestečko Partizánska L’upča, Zápisnice liptouského kontubernia

MZA Brno, G 12 Cerroniho sbirka 13. stol. - 1845, č. 37, inv. č. 38, Schulseminarien, Gymnasien und Schulen der Accatholischen in Mähren 1810

č. 88-89, inv. č. 90, Nachrichten von dem ehemaligen und gegenwertigen Zustand der akatholischen Gemeinden in Mähren. 1804

č. 91, inv. č. 92 Evangelische Pastoren und Schulrectoren in Boehmen před r. 1807

Bočkova sbirka, čís. 10.670 Paměti Pavla Urbanidesa

\section{Seniorátny archiv $\mathbf{v}$ Trenčine}

HOLUBY, J. L.: Nástín dejín bývalej ev. a. v. církve Ilavskej. Spísal Joz. L. Holuby, vyslúžilý ev. farár a. v. zemansko-podhradský a senior trenčianský. B. m., b. d.

PROCOPIUS, J.: Index rerum et verborum ... 1789. Rkp., III 2 C 52 (signatúra z Archivu ev. a. v. seniorátu nitrianskeho)

Protocolon sev liber continens articulos confessionis item leges et ordinem ... Anno Domini MDLXXX ...

\section{Turčiansky seniorátny archiv $\mathbf{v}$ Martine}

HOLUBY, J. L.: T. Sv. Martin. Turčiansky seniorátny archív Martin. Dejiny Turca a turčianskeho seniorátu. Písomný materiál 110. Dejiny Turca - historický materiál. Príloha listu Holuby O. Škrovinovi z Pezinku 24. 7. 1912, rkp.

Zápisnice turčianskeho turčianskeho kontubernia, 17.-18. stor., rkp.

\section{Slovenská národná knižnica, Archiv literatúry a umenia Martin}

Š. Adamovič. Dejiny novohradského seniorátu. Dobroč 107 K 2, Dolná Strehová 107 K 3, Kalinovo 107 K 9, Lešt’ 107 K 10, Lovibaña 107 K 11, Mašková 107 K 16, Polichno 107 L 2, Senné 107 L 5, Turíčky 107 L 6, Velký Krtíš 107 L 10, strojopis, nestr.

Annotationes per Rev. Dn. Thomam Dorothiczium ... consignatae et per Dr. Gabrielem Velovicz f. 30-45. Odpis Mateja Šuleka z roku 1786 MJ 303

Collectanea Laučekii - Epistolarum tom III. a VII. C 1069, Collectanea XIV. J 859

Daniel Krmana II. / ml./ kñaz, biskup, literát a trpitel. M 120 E 45 a 56 JJ 17

Daniel Sinapius-Horčička 56 AA 19

Diarium Andreae Thurii, f. 1-16 a Brevis Delineatio Virae Andreae Thurii, f. 17-19

Diarium Georgii Clementis (f. 20-25) a Diarium Zachariae Clementis (f. 25-29). Odpis Mateja Šuleka $z$ roku 1786 MJ 303

Gymnasiologia Evangelico-Hungarica ... Hanc Rezikio-Mathidesianam Gymnasiologiam variis ... descripsis Michael Rotarides Gömörino-Hungarus Anno 1746 Vittenberg ... J 1968

HOLUBY, J. L': Materiály k historii církevních sborov evanj. av. na území Trenčianskej Stolice stávavavšich a stávajúcich. II. Dolnotrenč. Contubernium. Sbierané Joz. L'. 
Holuby farárom zpodhradským a seniorom Trenčianským. (počiatok urobený r. 1884 v októbri.), J 3333

IOANNIS REZIK - GYMNASIOLOGIA EVANGELICO - HUNGARICA, sive HISTORIA SCHOLARUM et earundem RECTORUM CELEBRIORUM. Opera et studio M. SAMUELIS MATTHAEIDES alias Matthejeczi de Revisna Arvensis Nob. Hung., ... ad Annum MDCCXXIII eruta ... J 1967

Judita Masníková J. Domkovičovi 155 G 46, list z roku 1677, rkp.

List Daniela Dedinu z 13. novembra 1685 J 3373

Memorabilia Ecclesiae Evangelicarum Liptoviensium collecta per R. D. Matthiam Schulek Pastorem N. Palugyensem. Industria R. D. Alexandri Lichner, Pastoris Nem. Kostolanensis denuo MDCCCCLVI descripta stroj., SNK ALU Martin J 862

Pamatné prìhody Štěpán Pilárika Senického někdy kněze ... Wydal Bohuslav Tablic 1804, MJ 574

Vita nostri evangelici ... b m., 18. stor. J 3371

Series ordinatorum per Superintendentem ..., b. d., rkp., MJ 2

\section{Spolok svätého Vojtecha v Trnave}

fasc. 304, č. 8 Cirkevné dejiny Turzovky a celých Kysúc. Napísal farár Točík 1943 strojopis

Matricula Scholatica Juventutis R. M. Gymnasii Trenchiniensis ab anno 1655 inchoata, usque 1755 continuata, sign. AR I, n. 1. Spolok sv. Vojtecha v Trnave

\section{Státni okresni archiv Uherské Hradiště}

Fond archiv města Uherského Brodu, i. č. 54, Bartoškova kronika, rkp., s. 129

Pozůstalost Veleslava Růžičku, Náboženské poměry na Uherskobrodsku, Bojkovsku a Kloboucku v XV.-XVIII. století. Rkp., Praha 1934

\section{Tranoscius - Tranovského knižnica, Liptovský Mikuláš}

HOLUBY, J. L.: Krátke dejiny bývalej církve evanj. a. v. Bytčianskej, s filiálkami: Hliník, Hotešov / pozdejšie samostatná cirkev/, Chotešovka, Oblazov, Malá Bytča, Petrovice, Kolarovice /za čas samostatná cirkev/, Rovné /s kostolom/ a Setechov. Rkp. asi 1917

ten istý: Materiály k dejinám církve evanj. a. v. v stolici Trenčianskej. Sbierka II. Joz. Ludev. Holuby a. ev. farár Zemansko-Podhradský a t. č. senior Trenčianský 1887. ten istý: Materiály $k$ dejinám církvi evanjelických a. v. v Stolici Trenčianskej. Svazek V. diel 1. Církve ev. a. v. Contubernia horno-trenčianského čili Žilinského (S mapkou.). Diel I. Od Jozefa L'ud. Holuby-ho, farára ev. a. v. v Zem. Podhradského a na ten čas seniora Trenčianskeho. rkp. Zemianske Podhradie 1888 sv., 2. diel, rkp. 1888, ten istý: Materiály k dejinám církví evanjelických augšp. vyzn. v Stolici Trenčianskej. Svazek VI. diel' 1. Církve evanj. a. v. Contubernia dolño-trenčianského. Diel' I Joz. L'ud. Holuby farár Zem.-Podhradský a na ten čas senior Trenčianský. Sostavil Zemanskom Podhradi 1889, rkp. 
Fragmenta historica Ecclesiarum Euangelicarum Incyliti Comitatus Arvensis ... Opera et Studio Matthaiae Schulek ..., bez ev. č.

Memorabilia Ecclesiae Evangelicarum Liptoviensium, odpis M. Šuleka, bez ev. č.

\section{Ústredná knižnica SAV (Bývalá lyceálna knižnica) Bratislava}

Sors Danielis Krman superattendentis et V. D. Min., rkp., fasc. 234/4

Curricullum vitae Joannis Senioris Blasii 1684 töl 1763-íg., fasc. 237/2

Ordinačný list M. Sartoria, fasc. 682 Eredeti oklevek 4. Trencsén-Liptó és Árva

Tarnóczy Márton superintendens aláirása, rkp., fasc. 684/110

Danielis Krmanni Hungaria evangelica, rkp. z roku 1842 od L. Balogha, zv. 416

Regestá ista Ecclesiastica, per R. Dn. Joannem Hodikium ... opis Ludovita Balogha 1843, rkp. zv 363

REZIK, J.-MATTHAEIDES, S.: GYMNASIOLOGIA EVANGELICO - HUNGARICA, sive HISTORIA SCHOLARUM et earundem RECTORUM CELEBRIORUM. Opera et studio M. SAMUELIS MATTHAEIDES alias Matthejeczi de Revisna Arvensis Nob. Hung., nuper Lycei Eperiessiensis intra et ex Moenia moderatoris et simul Slavorum Nationis Pastoris, ex Authoris annotationibus autografois et aliorum documentis ad Annum MDCCXXIII ... zv. 480

Syllabus Litteratorum Thurocziensium ... Andreas Schmal... (1755) Ústredná knižnica SAV (Bývalá lyceálna knižnica) Bratislava, rkp. zväzky 79

Ústredný archiv ECAV na Slovensku Bratislava M. Šulek „Memorábilia“, bez ev. č. Variae Superintendentales et aliorum Matriculae atqvediiaria, nec non Catalogi Ecclesiarum, Superintendentium, Fautorum \& Persecutorum Ecclesiae aliaque ad Historiam Eccl. spectantia; ... colleta Opera et Studio Matthiae Schulek Ecclesiae Ev. Tiszóltzensis V. D Ministri

Triplicis Ordinis Matriculae Ordinatorum, a Rndissimis Dominis Superintendentibus ... Duplicis Ordinis Matriculae Ordinatorum, a Rndissimis Dnis Superintendentibus ...

\section{Author:}

Libor Bernát, Ph.D., ThMgr.

Slovak University of Technology in Bratislava

Faculty of Material Science and Technology in Trnava

Department of Engineer's Education and Human Sciences

Pavlínska 16

Trnava

91724

Slovakia

Email: libor.bernat@gmail.com 